\title{
THE AMENDMENTS OF THE CONSTITUTION OF 1945: ITS IMPACT ON INDONESIAN LEGAL SYSTEM
}

\author{
Budi Darmono ${ }^{1}$
}

\section{Abstrak}

The Constitution of 1945 was not amended for 54 years. Some people even regarded it as 'sacred' constitution because it was 'untouchable'. Some people said that it was not amended because it was advantageous for the rulers. This Constitution was, in fact, concise. It consisted of three parts. The first is Pembukaan or Preamble. The Preamble contained, and still contains the Pancasila, the state's fundamental norms. The second part is the Batang Tubuh or Body. This consisted of only 37 articles of primary provisions, 4 articles of transitional provisions, and 2 articles of additional provisions. The third part was the Penjelasan or Elucidation (explanatory memorandum). According to point IV of the Elucidation, the reason for the Constitution's conciseness was to avoid rigidity. The Elucidation described society as dynamic and volatile, especially in time of revolution. Therefore, if detailed matters were stipulated in the Constitution, the state might not have been able to keep up with the changes in society. Furthermore, point IV of Elucidation stated that despite the Constitution is concise, the most important thing in running the government is the semangat or spirit of those who run the government.

Keywords: constitution, amandement, legal system

\section{Brief History of the Constitution of $\mathbf{1 9 4 5}$}

The Constitution of 1945 was created in dying days of World War II in 1945. It was a time of uncertainty when Japanese occupation was almost over and Indonesian war for independence was about to begin. This was an emergency situation. An ad hoc committee was formed and they did not have time to stipulate detailed provisions. ${ }^{2}$ This suggests that the 1945

'Staf Pengajar di Fakultas Hukum Universitas Indonesia. Memperoleh gelar Sarjana Hukum dari Universitas Indonesia, Master of Science in Administration dari Central Michigan University dan Master of Comparative Law dari The George Washington University, serta memperoleh gelar Ph.D. dari Faculty of Law, The University of Melbourne. 
Constitution is temporary in nature and it can be seen in Aturan Tambahan or Additional Provision of the Constitution. Point 2 provides that, within 6 months of formation of Majelis Permusyawaratan Rakyat (MPR) or People's Consultative Assembly, the MPR should convene to determine a new constitution.

However, the time given by point 2 of Aturan Tambahan could not be fulfilled because it was interrupted by war between Indonesian nationalists and the Dutch who want to re-colonize Indonesia (the Dutch lost its colonial territory when the Japanese invaded it in 1942). As the effect of emergency situation, the President and a Komite Nasional or National Committee held legislative power. This revolutionary period lasted from 1945 to 1949 when the Dutch government handed its sovereignty over Indonesia to Indonesian government. ${ }^{3}$ The transitional constitutional period lasted until 1956 when the Konstituante or Constituent Assembly was ready to make a new constitution. During transitional period, the 1945 Constitution was substituted by the Undang-Undang Dasar Sementara 1950 or Provisional Constitution of 1950 .

The Konstituante was formed as the result of 1955 election. The Konstituante, however, failed to make a new constitution because members of the Konstituante could not resolve political deadlocks. ${ }^{4}$ Failure to make a new constitution caused political instability and uncertainty. President Soekarno responded it by issuing Presidential Decree of 1959. This Decree dissolved the Konstituante and re-enforced the 1945 Constitution. Therefore, the transitional period was prolonged or renewed until a new MPR was formed. This MPR was the result of election held in $1971 .{ }^{5}$ Instead of making new constitution, the MPR ratified the reapplication of the unamended Constitution of 1945. The Constitution prevailed until 1999.

Following the collapse of Soeharto administration in 1998, Indonesian politic entered new era that is called reformasi meaning the reform of political system which affects legal system. It initiated with the reform of

${ }^{2}$ Budi Darmono, 'Adat' and Land Law in a Plural System: A Study of Forestry Regulations and Indonesian 'Legal Development', Unpublished Dissertation, (Faculty of Law The University of Melbourne, 2004), p. 17-18.

${ }^{3}$ Mr. Mahadi, "Beberapa Sendi Hukum Di Indonesia: Pengantar Ilmu Hukum Indonesia, Jilid I, (Jakarta: PT. Penerbit dan Pertjetakan Saksama, 1954), hal. 16-17.

${ }^{4}$ Ismail Suny, The Review of Constitutionality of Decisions in Indonesia, In: University of Indonesia Law Journal, Vol.1, No.1, October 1999, (Faculty of Law University of Indonesia Publishing House, 1999), p. 14.

5 Abdullah Zaini, "Pengantar Hukum Tata Negara", (Jakarta: Pustaka Sinar Harapan, 1991), hal. 183. 
Laws that regulate political activities. The new Laws liberate political activities including freedom to establish political party. Liberation of political activities led to fair and free election that was held in 1999. The result of this election was the MPR which amended the Constitution of 1945 for the first time in 1999. The second amendment was done in 2000. The third amendment was performed in 2001 and once again the Constitution was amended in 2002 .

The process of amendment, however, was obstructed by different perception between the government and the MPR as to how it should be done. ${ }^{6}$ The government recommended that amendments will be prepared by Komisi Konstitusi or Constitutional Commission whereas the MPR preferred amendments through MPR debate. A compromise was reached through a decision to establish a Constitutional Commission that would work for and report to the MPR, pursuant to a Ketetapan MPR (MPR Decision) No.I/2002. ${ }^{7}$ The Constitution was, finally, amended. It is no longer concise. Although it still consists of 37 articles, they are greatly expanded. For example Article 28 is followed by Article 28A, 28B, 28C and so forth. Thus the number of provisions in the amended Constitution is much more detailed and lengthy. It is now equivalent to 73 articles.

As the effect of these amendments, the system of the government, presidential power and judiciary system are modified.

\section{Purposes of Amendments}

First, the amendment purports to minimize the risk of abuse of power. Article 7 of the first amendment of 1999 limits the presidency to two terms. Before amendments, although the length of period of presidency is 5 year, there is no limitation of term for a person to become president. This provision enabled Soekarno to hold presidency for 21 years and Soeharto to become president for 32 years. Article $6 \mathrm{~A}$ of the third amendment of 2001 stipulates that the President and the Vice President are directly elected by the people. Before amendments, the President and the Vice President were elected by members of the MPR. This mechanism

${ }^{6}$ Tim Lindsey, Indonesian Constitutional Reform: Mudding Toward Democracy, In: Singapore Journal of International and Comparative Law: Comparative Constitutionalism: The Remaking of Constitutional Orders in South-East Asia, (2002), 6 Sing JICL, 2002, p. 246, 249.

${ }^{7}$ Budi Darmono, Op. Cit., p. 18. 
had the risk of political bargaining, power play and money politic between the legislative and the executive.

Second, the purpose of amendments is to protect human rights. Before amendments, human rights were merely and shortly stipulated in Article 27, 28, and 29. Point 2 of Article 27 stipulated that every citizen has the right of decent job and life. Article 28 concerned about freedom to establish organization and meeting, and freedom of expression. Point 2 of Article 29 guaranteed freedom for every person to adhere religion and belief.

After amendments, human rights are stipulated in lengthy and detailed provisions. It is stipulated in Article 28A to Article $28 \mathrm{~J}$. Article $28 \mathrm{~A}$ concerns the right to live. Article $28 \mathrm{~B}$ guarantees the right for every person to have family and children through marriage. This Article also guarantees every child to grow and to free from discrimination and violence. Article $28 \mathrm{C}$ stipulates that every person is entitled to self-develop and to have education in order to improve his/her life. Article 28D concerns equality before the law, fair treatment and status of citizenship. This Article also guarantees equality of opportunity to have job in government. Article 28E guarantees freedom for every person to adhere religion, to choose education, job, citizenship, and domicile. This Article also guarantees freedom of expression and freedom to establish organization. Article $28 \mathrm{~F}$ relates to right of information. Article $28 \mathrm{G}$ respects the right of dignity and the right to free from torture and indecent treatment. This Article also respects the right to seek political asylum from foreign country. Article $28 \mathrm{H}$ stipulates that every person is entitled to have prospered life and social security. Every person is entitled to have equal opportunity. Every person is entitled to have social security. Every person is entitled to have properties and nobody can arbitrarily take over these properties. Article 28I states that right to live, right to free from torture, right of expression, right to adhere religion, right to free from slavery, right to be legal person, and right to free from legal charge of retroactive law, are rights that cannot be denied in any circumstances. This Article also protects every person from discriminative treatment. Furthermore, this Article acknowledges cultural identity and right of traditional communities. This Article states that protection of human rights is responsibility of the state, especially the government. Constitutional human right provisions shall be applied by Laws. Article $28 \mathrm{~J}$ declares that everybody should respect human rights. 
Third purpose of amendments is to delegate additional power to provincial and regency government. This delegation of power is stipulated in Article 18,18A, and 18B. Before amendments, regulation concerning natural resources gave central government much power to manage natural resources. Most of earning from natural resources went to central government and then central government distributed it to provincial governments. This regulation disappointed provinces which have rich natural resources. Power to regulate infrastructure, agriculture, and public health was also in the hand of central government.

After amendments, larger part of earning from natural resources goes to provincial and regency governments from which those natural resources are exploited. Provincial and regency governments are now given more power to regulate infrastructure, agriculture, public health and other fields.

Fourth purpose of amendments is to strengthen the principal of checks and balances in the government. Before amendments, the executive dominated the government. After amendments, other branches of government are more empowered. The branches of government are now dealt with in governing the state in a much more balanced way.

\section{The System of the Government}

Indonesia is still searching a permanent system for its government since the establishment of the state. When it was established in 1945, Indonesia was unitary states. It changed to federation states as the result of a long negotiation process with the Dutch government. It returned to the system of unitary along with political change. Arguably, Indonesia is regarded to apply a presidential system. In its history, however, Indonesia was not consistent with this system. In certain periods, although the head of government was the President, the Prime Minister held significant power as if it is parliamentary system. The power, then, shifted again to the President. The volatility of the system was the effect of endless power struggle of political parties or politicians.

\section{A. Pre-Amendment of the Constitution of $\mathbf{1 9 4 5}$}

As mentioned, the Indonesian government system is arguably regarded as presidential government system because the President 
appoints and dismisses the ministers, and leads executive branch. The executive branch is divided into departments, state ministries, and government agencies. The President and ministers have the power to interpret and implement the Laws through government regulations, presidential decisions, and ministerial decisions.

Sri Sumantri has, however, argued that Indonesian system contained both presidential and parliamentary characteristics. Parliamentary characteristics can be seen in the power, held by the MPR, to dismiss and appoint the President. Presidential characteristics can be seen in the great executive power held by the President and in the fact that ministers were appointed and dismissed by the President. ${ }^{8}$ The combination of presidential and parliamentary characteristics can also be seen in accountability system. The President was responsible to the MPR, as in parliamentarian system. On the other hand, the ministers are responsible solely to the President and not to the parliament, as in a presidential system. ${ }^{9}$

Therefore, Azhary has argued that this form of Indonesian government is appropriately named to be the MPR government system. His argument is based on five reasons. First, the MPR holds the highest power of state. Second, state activities are centered on the MPR. Third, the DPR, the legislature, is part of the MPR which is the parliament meaning the legislature that holds sovereignty. Fourth, the President is appointed and dismissed by the MPR. Fifth, the MPR is empowered to amend and stipulate the Constitution and the Garis Besar Haluan Negara or State Guide Lines that function as a framework for government policy. ${ }^{10}$

The MPR also held people's sovereignty. The MPR's supremacy has two aspects, namely, legal power and the absence of any contending authority. ${ }^{11}$ This power was, then, delegated to the President as one executive body; to the DPR as the legislative body; and to the MA as the judicative body. The MPR's power was also

${ }^{8}$ Sri Sumantri, "Sistem-Sistem Pemerintuhan Negara-Negara ASEAN", (Bandung: Transito, 1976), hal. 52, 54-56.

9 Mohamad Kusnardi, dan Bintan Saragih, "Susunan Pembagian Kekuasaan Menurut UUD 45", (Jakarta: Gramedia, 1978), hal. 69.

${ }^{10}$ H. Azhary, Negara Hukum Indonesia: Suatu Analisis Yuridis Normatif tentang Unsur-Unsurnya (Ringkasan Disertasi), Program Pasca Sarjana Universitas Indonesia, 1993, hal. 14-16.

${ }^{11}$ Suny, Op. Cit., p. 16. 
delegated to the Badan Pemeriksa Keuangan (BPK) or State Audit Body, which monitors state assets; and to the Dewan Pertimbangan Agung (DPA) or Supreme Advisory Council, which functions as advisory body to the executive. ${ }^{12}$

Although the MPR was the highest and most powerful state institution, the MPR did not run the country in daily bases. During its 5-year period, the duty of the MPR was to appoint the President and to make State Guide Lines. The President was subordinated to the MPR. In the end of presidential tenure, the President has to report to the MPR. The MPR then judges presidential accountability and decide whether the MPR accept it or not.

Part of members of the MPR was members of the DPR which its main duty was to supervise and control the President in day-to-day running the country and in implementing the State Guide Lines. Another duty was, together with the President, to make Laws. The DPR is equal to the President. The DPR has no power to dismiss the President. Vice versa, the President cannot dissolve the DPR.

In financial field, the President is controlled by the DPR and the BPK. The annual state budget is subject to DPR approval. State earnings and expenses are subject to BPK audit. For that reason, according to the Constitution, the BPK is not subordinated to the President. The BPK is, therefore, an external auditor for the government.

\section{B. Post Amendments of the Constitution of $\mathbf{1 9 4 5}$}

Part of MPR's power was stripped. The MPR does not hold people's sovereignty. The sovereignty is returned to the people. The MPR does not appoint the President any longer because the President is elected by the people. The MPR is no longer the highest state body. The President is no longer responsible to the MPR. As a consequence, the President does not have to report to the MPR. Although the MPR still hold the power to dismiss the President, the presidential dismissal requires a long and tight procedure. In this procedure, the DPR and the Mahkamah Konstitusi (MK) or Constitutional Court are involved. The State Guide Lines does not exist any longer. The main duty of the MPR is now to amend the existing constitution or to make new constitution. However, this duty is not necessarily done as long as the existing constitution is adequate and accommodative to the popular

${ }^{12}$ Budi Darmono, Op. Cit., p. 20. 
needs and aspirations. After amendments of the Constitution, the system of the government is no longer the MPR system. It cannot also be called the parliamentarian system because parliamentarian characteristics do not exist. It is now appropriate to be named the presidential government system.

New state bodies were established: the Dewan Perwakilan Daerah (DPD) or Provincial Representative Council and the Mahkamah Konstitusi (MK) or Constitutional Court. Members of the DPD are directly elected by the people of the provinces they represent. Members of the DPD do not represent political parties. They represent provincial aspirations and interests. The number of provincial representative in the DPD is equal for every province regardless the number of population. The DPD involves only in five matters: regional autonomy; relationship between central and provincial or regency government; formation, division, and merger of province or regency; management of natural and economic resources; and financial balance between central, provincial and regency government. The DPD are active in Law-making process relating to such matters and they supervise the enforcement of such Laws. Members of the DPD are members of the MPR.

The MK (Constitutional Court) has five duties. First, it presides over cases that review Law. Second, it presides over cases regarding disputes between branches of government. Third, it dissolves political parties. Fourth, it presides over cases concerning results of elections. Fifth, it delivers legal opinion in the process of presidential or vice presidential impeachment. Chief Justice of the MK is elected among and by Constitutional Court judges.

\section{Presidential Power}

In Indonesian record of presidency up to date, two most powerful and influential presidents were Soekarno, the first president, and Soeharto, the second. They also ruled the country in long periods: 21 years by Soekarno and 32 years by Soeharto. The source of Soekarno's political power and influence was his charisma. Soeharto, on the other hand, carefully built formal legal system to pin his political power and influence.

\section{A. Soekarno Administration}

As above mentioned, in its history, the Indonesian government system was volatile. Despite the system is arguably regarded as 
presidential system, the President, during Soekarno administration, sometimes had to share his executive power with the Prime Ministers. This power sharing took place from 1945 to 1959 . The presidential system was also interrupted by parliamentarian system as the result of the 1955-election. It lasted only 4 years before the system was returned to the presidential system by the 1959 Presidential Decree. Since 1959, political power of the President had increased significantly because the Decree dissolved the parliament and the President formed new temporary parliament: the Majelis Permusyawaratan Rakyat Sementara (MPRS) or Provisional People's Consultative Assembly. The members of this parliament were appointed by the President and not elected by the people. The members of the DPR were also appointed by the President. In executive branch, the President was also the Prime Minister and he appointed the Deputy Prime Minister. In judicative branch, the President appointed Chief Justice. In this period, three branches of government were controlled by the President.

\section{B. Soeharto Administration}

Soeharto had different style to Soekarno in governing the country. $\mathrm{He}$ formally obeyed the Constitution of 1945. He, however, implemented the Constitution in a way that accumulates power through legal system. He used the conciseness of the Constitution. As mentioned, the Constitution of 1945 was created in emergency situation. It only stipulated general provisions. These provisions had to be applied by Laws. Through Law-making process, he inserted his aspirations. The Laws, thus, were application of his will.

Initially, he developed the Golongan Karya, a political party, as a vehicle. He was the most powerful figure in this party. This party was supported by the bureaucracy and the military which were under his control. These supports can be seen especially in elections. With the supports of two significant state apparatus, the Golongan Karya dominated Indonesian politic during Soeharto administration. As a corollary, the Golongan Karya was dominant in the MPR and the DPR. Through his influence in the MPR and the DPR, the President had no significant obstacle in re-appointing in presidential process and making the Laws. Influence over the MPR and the DPR was pivotal because the MPR had the power to appoint and dismiss the President and the Laws are subject to DPR approval. He then made the Laws that strengthened his power, such as the Laws that empowered him to appoint part of members of MPR and DPR and the Laws that limited the number of political parties. In addition, he was empowered to 
declare the state in emergency. In state emergency situation, he held an extraordinary power. It can be seen in the establishment of Komando Operasi Pemulihan Keamanan dan Ketertiban (Kopkamtib) or the Command of Operation to Restore Security and Order. The establishment of this government institution was stipulated in MPR decision. This government institution had extraordinary powers, such as interrogating and detaining persons without legal charges.

Subsequently, the Laws also empowered the President to intervene in judiciary system. Chief Justice was appointed by the President. The Minister of Justice was also authorized to determine judicial appointment, promotion, salary and dismissal. Through this provision, the President, as the superior of the Minister of Justice, could profoundly influence the judicial system. ${ }^{13}$ Additionally, the President had the power to appoint the Chairman of BPK, a state body whose duty is to financially audit the government. Through this power, the President could also influence the BPK.

During Soekarno and Soeharto administrations, political power was arrogated in the hand of the President. Separation of power was reduced into division of power meaning the President can influence, interfere, and even control other state branches. Centralization of power was facilitated by the provision of the Constitution. Before amendment, the Constitution rendered people's sovereignty to the MPR. The MPR then distributed the power to the DPR, the President, the MA, and the BPK. In Soekarno and Soeharto administrations, the President simply influenced the MPR to control people's sovereignty.

\section{Post Amendments of the Constitution of $\mathbf{1 9 4 5}$}

After amendments of the Constitution, presidential power was trimmed. The President has no power to appoint members of the MPR and the DPR. All members are now should be elected. In addition, the President is not empowered to appoint Chief Justice and Chairman of the BPK, State Audit Body. The President, therefore, is not influential to these state institutions. These state institutions purported, and still purport to supervise and control the President. Along with diminishing presidential influence, these state institutions are now more independent and function well. The power of the Minister of Justice, the President's subordinate, was also reduced, especially in judiciary

${ }^{13}$ Timothy Lindsey, (ed.). "Indonesia: Law and Society", (Sydney: The Federation Press, 1999), p. 13, 14. 
system. The power of the Minister of Justice to determine judicial appointment, promotion, salary and dismissal has been stripped. The President, as the Minister's superior, has no influence in judiciary system any longer. The judicial power is now more independent.

\section{The Parliament}

\section{Pre-Amendments of the Constitution of $\mathbf{1 9 4 5}$}

The parliament was divided into two state bodies: the MPR and the DPR. The MPR consisted of the whole members of the DPR and the Utusan Golongan or representative of groups, for example, representative of the Armed Forces, representative of provinces. All members of the Utusan Golongan were appointed by the President. The duty of the Utusan Golongan was to protect the interests of the group they represent. In practice, the Utusan Golongan was extension of presidential aspirations.

As mentioned, the duty of the DPR is to supervise and control the executive. Another duty of the DPR is, together with the President, to make Laws. However, before the amendments, the process of Law-making was dominated by the executive. The role of the DPR was to approve the Bills. In practice, initiative to make Laws came from the executive. In the first stage, each department or government institution prepared draft Laws. Second stage, the draft Laws went to Secretary of State for presidential consideration. Third stage, the draft Laws were sent to the DPR to be debated and voted. If the DPR approved, the President ratifies the Laws and the Secretary of State, by the order of the President, promulgates it. ${ }^{14}$ The reason why the executive took initiative is that the executive was more capable in preparing the draft Laws. They have more expertise and fund than the legislative.

In taking the role to supervise the executive, the DPR had difficulty to effectively control the President since part of members of the DPR was appointed by the President during Soeharto administration. Beside, most elected members in the DPR were from Golkar, Soeharto's party. In Soekarno

${ }^{14}$ Maria Farida Indrati Soeprapto, "Ilmu Perundang Undangan: Dasar-Dasar dan Pembentukannya: Disarikan dari Perkuliahan Prof. Dr. A. Hamid S Attamimi, S.H.", (Yogyakarta: Kanisius, 1998), hal. 134. 
administration, since 1959, all members of the DPR were appointed by the President.

\section{Post-Amendments of the Constitution of $\mathbf{1 9 4 5}$}

The parliament is now divided into three state bodies: the MPR, the DPR, and the DPD. The MPR consists of members of the DPR and members of the DPD. All members of the MPR are elected. The Utusan Golongan does not exist any longer.

Among three parliamentary bodies, the DPR is now the most influential body for two reasons. First, all members of the DPR are elected. None of them is appointed by the President. This makes the DPR independent. The President itself is directly elected by the people. This means that the President does not depend on major political parties. The DPR is, of course, dominated by major political parties. Therefore, major political parties are not necessarily President's party. The DPR, thus, is not always supporter of the President. The consequence is that the DPR can effectively and independently control and supervise the President. Second, another duty of the DPR is to make Laws. Before amendments of the Constitution, initiative of Law-making was from the President and his/her subordinates and process of Law-making was dominated by the executive. The DPR was active only in final stage. After amendments, the Constitution empowers the DPR to make draft of Laws and provides significant role in Law-making process.

The role of the DPD in Law-making process is less than the DPR's. The DPD involves in Law-making process only if the Laws concern provincial and regencies interests. At present, the DPD demands more power in Law-making process, but it has to amend the Constitution. So far the DPR has not agreed yet.

\section{E. The Judicial System}

\section{Pre-Amendments of the Constitution of $\mathbf{1 9 4 5}$}

The Constitution of 1945 declares judicial power is independent. The Law also states that the judges are independent in making court decisions. However, the Laws stipulated that judicial promotion, appointment, salary, dismissal, and even tour of duty were determined by the Minister of Justice. In other words, the judges were independent in judicial aspect but 
dependent to the Minister in administrative aspect. Since the Minister of Justice is President's subordinate, the judges were dependent on the executive. The Minister was, thus, very influential in judiciary system. Besides, Chief Justice was appointed by the President. Therefore, in many cases involving government or government officials, the judges tended to protect government or government officials' interests when they presided over such cases, for example, the Tulang Bawang case, the Mentawai case, the Kedung Ombo case, and the Alastelogo case. In these legal disputes, the people were against government officials, government institutions and state-owned companies. All court decisions in these case were in favor of government officials, government institutions and state-owned companies (Darmono: 2004; 130, 141, 160, 172). ${ }^{15}$

\section{The Power of Judicial Review}

The Constitution of 1945 empowered the Supreme Court (MA) to judicially review government regulations and other regulations and instruments below the level of statute. These laws are made by the executive. The MA, thus, has the power to declare these laws as null and void if the MA considers these laws are deviant or in contrary to Laws or statutes that are subject to DPR approval. The procedure for judicial review was stipulated in Article 26 of Law No.14/1970 and Article 31 of Law No.14/1985. The MA has, however, never effectively used such power. ${ }^{16}$ The MA was reluctant to use its power because the MA depended on the President and the judges were dependent to the Minister of Justice.

Therefore, so long as deviant government regulations and other lower-level laws are not declared null and void, they are still valid and can be effectively enforced. ${ }^{17}$

There is no special court for cases concerning corruptions and human right violations. Corruption cases were presided over

${ }^{15}$ Budi Darmono, Op. Cit., p. 130, 141, 160, 172.

16 Paulus Effendie Lotulung, Judicial Review in Indonesia, In: University of Indonesia Law Journal, Vol.1, No.1 October 1999, (Faculty of Law University of Indonesia, 1999), p. 47-49.

${ }^{17}$ Budi Darmono, Op. Cit., p. 180. 
dependent to the Minister in administrative aspect. Since the Minister of Justice is President's subordinate, the judges were dependent on the executive. The Minister was, thus, very influential in judiciary system. Besides, Chief Justice was appointed by the President. Therefore, in many cases involving government or government officials, the judges tended to protect government or government officials' interests when they presided over such cases, for example, the Tulang Bawang case, the Mentawai case, the Kedung Ombo case, and the Alastelogo case. In these legal disputes, the people were against government officials, government institutions and state-owned companies. All court decisions in these case were in favor of government officials, government institutions and state-owned companies (Darmono: 2004; 130, 141, 160, 172). ${ }^{15}$

\section{The Power of Judicial Review}

The Constitution of 1945 empowered the Supreme Court (MA) to judicially review government regulations and other regulations and instruments below the level of statute. These laws are made by the executive. The MA, thus, has the power to declare these laws as null and void if the MA considers these laws are deviant or in contrary to Laws or statutes that are subject to DPR approval. The procedure for judicial review was stipulated in Article 26 of Law No.14/1970 and Article 31 of Law No.14/1985. The MA has, however, never effectively used such power. ${ }^{16}$ The MA was reluctant to use its power because the MA depended on the President and the judges were dependent to the Minister of Justice.

Therefore, so long as deviant government regulations and other lower-level laws are not declared null and void, they are still valid and can be effectively enforced. ${ }^{17}$

There is no special court for cases concerning corruptions and human right violations. Corruption cases were presided over

${ }^{15}$ Budi Darmono, Op. Cit., p. 130, 141, 160, 172.

16 Paulus Effendie Lotulung, Judicial Review in Indonesia, In: University of Indonesia Law Journal, Vol.1, No.1 October 1999, (Faculty of Law University of Indonesia, 1999), p. 47-49.

${ }^{17}$ Budi Darmono, Op. Cit., p. 180. 
in ordinary criminal court. Cases involving human right violations have never been presided over.

\section{Post-Amendments of the Constitution of $\mathbf{1 9 4 5}$}

The President and the Minister of Justice's power to interfere in judicial system were stripped. Chief Justice is elected by Supreme Court judges. Power for judicial promotion, appointment, salary, dismissal and tour of duty were shifted to the Supreme Court. The MA and the judges are now independent.

\section{The Powers of Judicial Review}

At present, the powers of judicial review are held by the MA (Supreme Court) and the MK (Constitutional Court). The MA is authorized to judicially review government regulations and other regulations below the level of statute, whereas the $\mathrm{MK}$ is authorized to judicially review the Laws (statutes). The MA could declare government regulations and other regulations as null and void because they are deviant or in contrary to Laws, and the MK could declare Laws as null and void because they are deviant or in contrary to the Constitution. In other words, the MA is the guardian of Laws and the MK is the guardian of the Constitution.

\section{Special Courts}

Special court for human right violation can be established if there is human right violation. The DPR, however, is in disputes with the Jaksa Agung or Attorney General on how such special court is established. The Attorney General stated that special court for human right violations could be established if the DPR finds human right violations. The DPR, on the other hand, argues that it should not depend on the DPR's finding of human right violations. According to the DPR, the Attorney General is the institution to find human right violations and following Attorney General's finding of human right violations, the special court for human right violations can be established.

Special court for corruption has been established. However, the $\mathrm{MK}$ in its decision considered that legal base for establishing special court for corruption must be strengthened through Law. 


\section{F. Commitment to Pancasila and the Principle of 'Negara Hukum'}

\section{The Pancasila}

Pancasila is the state grundnorm: the foundation and source for state regulation. ${ }^{18}$ It is also the foundation of state. Pancasila contains five basic principles, namely belief in God, humanity, unity, democracy, and social justice. As the foundation of state, Pancasila is, thus, the main reference and guide for all laws and state policies. Therefore, Pancasila is also used as a parameter to examine whether Constitution, Laws or regulation below Laws are in line with its basic principles. ${ }^{19}$ Pancasila is also a consensus of the people of Indonesia. Pancasila is written in the Preamble of the Constitution of 1945.

However, over five decades since the establishment of the Republic, there have been numerous serious departures by successive administrations from the values embodied in Pancasila. Humanity, democracy and social justice are the values that are frequently ignored by the government. ${ }^{20}$

Although the Constitution of 1945 was amended four times, a Preamble of the Constitution remains, and Pancasila, thus, is kept untouched. A reason to keep Pancasila is that Pancasila is a foundation of the state. If Pancasila is erased or modified, the foundation of the state will be dismantled. A form of the state will change and a popular consensus will be betrayed. Political cost will be too high because it will generate political disputes and even chaos. Denial to Pancasila will also be regarded as denial of basic values of the people.

\section{The Principle of 'Negara Hukum'}

The Constitution of 1945 clearly states that Indonesia is negara hukum or rechtsstaat, literally, a 'law state' or 'a nation of law'. ${ }^{21}$ This terminology appeared in the Elucidation concerning

\footnotetext{
${ }^{18}$ Maria Farida Indarti Soeprapto, Op. Cit., hal. 40.

${ }^{19}$ Budi Darmono, Op. Cit., p. 12.

${ }^{20}$ Ibid., p. 12, 13.
} 
the sistem pemerintahan negara or state government system. It stated that negara Indonesia berdasarkan atas hukum (rechtsstaat), tidak berdasarkan atas kekuasaan belaka (machtsstaat) meaning: the Indonesian state is based on law and not merely based on power.

This notion has been considered to be loosely equivalent of Western notion of the 'rule of law', although it does not have precise similarity. ${ }^{22}$ Rechtsstaat is a civil law idea while "rule of law' is a common law notion, at least in its origin. The notion of 'rule of law' was gradually formed through a long history in England before it was formally defined. ${ }^{23}$ The 'rule of law' definition includes supremacy of law, equality before the law, and constitution based on human rights. ${ }^{24}$ The rechtsstaat is, however, a more limited idea, relying more on procedural correctness. However, while negara hukum was originally identical to rechtsstaat, it has gradually moved closer to common law idea of separation of powers in common understanding, especially after the collapse of Soeharto government. ${ }^{25}$

The principle of rechtsstaat contains three basic ingredients: a guarantee of human rights protection; an independent judiciary; adherence to the principle of legality ${ }^{26}$, and administrative court that mediates disputes between the state and citizens. ${ }^{27}$

Although the Constitution of 1945 clearly stated that Indonesian state is negara hukum meaning the state is based on law, Soekarno and Soeharto had their versions. During Soekarno administration, politic was given priority. Soekarno told to the

\section{${ }^{21}$ Ibid., p. 13.}

${ }^{22}$ Timothy Lindsey, Op. Cit., p. 13.

${ }^{23}$ David Clark, The Many Meanings of Rule of Law, In: Kanishka Jayasuriya (ed), Law, Capitalism and Power in Asia: The Rule of Law and Legal Institutions, (Routledge, London \& New York, 1999), p. 29-34.

${ }^{24}$ Padmo Wahjono, "Membudayakan Undang-Undang Dasar 1945", (Jakarta: IndHill-Co, 1991), hal. 40, 41 .

${ }^{25}$ Tim Lindsey, Op. Cit., p. 244-250.

${ }^{26}$ JHA. Logemann, Het Staatsrechten van Indonesia, (Bandung: NV Uitgeverij W van Hoeve, 1954), p. 18.

${ }^{27}$ Todung Mulya Lubis, The Rechtsstaat and Human Rights, In: Timothy Lindsey (ed), Indonesia: Law and Society, (Sydney: The Federation Press, 1999), p. 172. 
people that revolution has not been finished yet, although in that time Indonesia has been independent. Therefore, political goal could set the laws aside. During Soeharto administration, economic development and political stability were given priority. Laws were dedicated to them.

Soekarno and Soeharto interpreted the principle of negara hukum from their own point of view. Soekarno subordinated the laws to his revolutionary policies whereas Soeharto subordinated the laws to his stability, security, order and economic development policies. ${ }^{28}$

Soeharto is, however, different to Soekarno. Soeharto adhered to legal procedures while Soekarno did not. It can be seen when Soekarno dissolved democratically-elected parliament with his Presidential Decree in 1959 and reinstated the Constitution of 1945 replacing the Provisional Constitution of 1950. Soeharto, as above described, achieved his goals through legal system. The similarity of both presidents is that they sometimes sacrificed human rights in achieving their goals, for example, imprisoning their opponents.

After the fall of Soekarno and Soeharto, the Elucidation of the Constitution of 1945 was repealed by fourth amendment in 2002 but the principle of negara hukum still exists and now appears in the body of the Constitution in Article 1 point 3.

The existence of the principle of negara hukum in the amended Constitution demonstrates political will of Indonesian leaders and politicians in reformasi period to commit to this principle. Leaders and politicians in this period frequently state that one of reformasi objectives is to put the state back on the right track. They argued that during Soekarno and Soeharto administrations, Indonesian state applied the principle of machtsstaat (state is based on power) and not rechtsstaat (state is based on law). They, thus, have intention to correct their predecessors. They also realize that the conciseness of the Constitution of 1945 will provide a chance for the President to abuse his/her power. To prevent this, they amended the Constitution in detailed and lengthy provisions. 


\section{Scattered Power and Effectiveness of Government}

Indonesia is a country with more than 200 millions population living over across seventeen thousand islands in highly varied cultural, social and economic conditions. Governing Indonesia is really hard task.

For hundreds years, the people of Indonesia lived under indigenous and foreign authoritarian monarchs. After independence, they were ruled by two powerful presidents. They are, thus, familiar with absolute power. Living under democratic atmosphere is a new experience. Even the leaders and politicians have no enough idea on how to rule democratically. Democracy is regarded only as freedom. Many people including leaders and politicians do not see another aspect of democracy that is responsibility. Eight years of reformasi showed that Indonesian democracy has not been mature yet.

After constitutional amendments, power is well distributed to branches of government. Power is no longer centralized in the hand of the President. The President has less power but has more legitimacy. Other state bodies, such as the DPR is becoming more powerful. The distribution of power is not only horizontal but it is also vertical. At present, provincial and regional government are more powerful than before amendments. The effect is a competition of power.

Reformasi period is dotted with riot, disorder demonstrations, social unrest, increasing certain crime such as illegal logging, fishing and mining, power struggles, and bickering between state branches, provincial and regency governments. This exhausts resources. Government leaders and politicians are distracted. They cannot focus on governmental program.

Riot, disorder demonstrations, increasing certain crime rate and social unrest are caused by some factors. Freedom is misinterpreted and, thus, misused. Law enforcement is weak and sometimes it can be compromised because the police are haunted by accusation that they violate human rights. Certain crime, such as illegal logging and mining, involved mass perpetrators. Law enforcement against this crime sometimes generates economic, political and social issues. These issues led to weaken law enforcement.

Power struggles is still taking place because the situation now provide opportunities for politicians, and even instant politicians to gain power. Sometimes ethical conduct is ignored.

Horizontal dispute between branches of government and vertical dispute between central, provincial and regency governments are generated because new laws do not clearly describe and define authorities, responsibilities, obligations and rights of these state apparatus and bodies. Law makers do not have adequate time and resources to do their jobs. There 
are so many things to regulate and there is so little time. One example is regulation concerning exploitation and management of natural resources. Another example is regarding public health service.

The effect is that government cannot effectively apply its program. One program is to increase economic growth. This requires new investments but many investors are reluctant because security is not guaranteed and legal certainty is doubtful. Another program is to strengthen security. Application of this program is also hampered by increase of crime rate and social unrest.

\section{A New Hope}

Although the government is not so effective, there is a new hope in Indonesia. A democratic condition provides unlimited opportunities for people to self-develop. Information is not censored any longer and press is free. The people are relatively free from intimidation and threat coming from ruler. Democracy needs time to be mature as happens in many countries. When the people well fit with democracy, the government will be effective and the situation will be better off. However, this needs consistent efforts to educate people about democracy. 


\section{References}

Azhary, H. Negara Hukum Indonesia: Suatu Analisis Yuridis Normatif tentang Unsur-Unsurnya, (Ringkasan Disertasi), Program Pasca Sarjana Universitas Indonesia, 1993.

Darmono, Budi. 'Adat' and Land Law in a Plural System: A Study of Forestry Regulations and Indonesian 'Legal Development', Unpublished Dissertation, Faculty of Law The University of Melbourne, 2004.

Clark, David. The Many Meanings of Rule of Law, In: Kanishka Jayasuriya (ed), Law, Capitalism and Power in Asia: The Rule of Law and Legal Institutions, Routledge, London \& New York, 1999.

Kusnardi, Mohamad. dan Bintan Saragih, Susunan Pembagian Kekuasaan Menurut UUD 45, Jakarta: Gramedia, 1978.

Lindsey, Timothy. (ed.). Indonesia: Law and Society, Sydney: The Federation Press, 1999.

Lindsey, Tim, Indonesian Constitutional Reform: Mudding Toward Democracy, In: Singapore Journal of International and Comparative Law: Comparative Constitutionalism: The Remaking of Constitutional Orders in South-East Asia, (2002), 6 Sing JICL, 2002.

Logemann, JHA. Het Staatsrechten van Indonesia, Bandung: NV Uitgeverij W van Hoeve, 1954.

Lotulung, Paulus Effendie. Judicial Review in Indonesia, In: University of Indonesia Law Journal, Vol.1, No.1 October 1999, Faculty of Law University of Indonesia, 1999.

Lubis, Todung Mulya, 1999, The Rechtsstaat and Human Rights, In: Timothy Lindsey (ed), Indonesia: Law and Society, Sydney: The Federation Press, 1999.

Mahadi, Mr. Beberapa Sendi Hukum Di Indonesia: Pengantar Ilmu Hukum Indonesia, jilid I, Jakarta: PT. Penerbit dan Pertjetakan Saksama, 1954.

Soeprapto, Maria Farida Indrati. Ilmu Perundang Undangan: Dasar-Dasar dan Pembentukannya: Disarikan dari Perkuliahan Prof. Dr. A. Hamid S Attamimi, S.H, Yogyakarta: Kanisius, 1998.

Sumantri, Sri. Sistem-Sistem Pemerintahan Negara-Negara ASEAN, Bandung: Transito, 1976.

Suny, Ismail. Mekanisme Demokrasi Pancasila, Jakarta: Aksara Baru, 1978. 
. The Review of Constitutionality of Decisions in Indonesia, In: University of Indonesia Law Journal, Vol.1, No.1, October 1999, Faculty of Law University of Indonesia Publishing House, 1999.

Wahjono, Padmo. Membudayakan Undang-Undang Dasar 1945, Jakarta: Ind-Hill-Co, 1991.

Zaini, Abdullah. Pengantar Hukum Tata Negara, Jakarta: Pustaka Sinar Harapan, 1991. 